\title{
EDUCATION AND INDUSTRIALIZATION: THE PLACE OF WOMEN
}

\author{
Nneka Umejiaku \\ Nnamdi Azikiwe University, Awka,
}

\begin{abstract}
:
The role of women in industry can never be overemphasized because education and industrialization are veritable tools for emancipating women from poverty. This study examines the position of women in industry and finds that African women, particularly Nigerian women do not thrive in industry like their male counterparts due to many factors that inhibit them. These factors include legal and traditional practices that are rooted in our culture. Apart from legal factors, the work finds some cultural factors like early marriage and widowhood practices that are inimical to participation of women in industry. The work recommends that Nigerian laws should be reviewed, particularly the 1999 Constitution which should be made gender sensitive, so that women will be empowered to participate fully in industry. Also, all obnoxious cultural practices that are inimical to participation of women in industry should be jettisoned.
\end{abstract}

\subsection{Introduction:}

Industrialization is a major key to development in every successful nation in the world. In fact, historical evidence shows that the use of industries, trade, technology and the right policies were the major ingredients in their successful transformation (Lin and Monga, 2010). Also, empirical evidence from developed, newly industrializing and major economies has shown that sustainable development cannot be achieved on a weak industrial base (Lall, 1999). Thus, the issue that this brings to the fore is, the place or position of women in industry. This issue is very imperative because we are in an era where women are taking positions they had never been holding before like presidents of nations, captains of industries, senators et cetera. However, many women are still left out because of many drawbacks. Hence, this work examines the challenges and prospects of women in industries and makes a serious case for a review of the laws for the protection of women in every sphere, by eradicating customary practices that are inimical to their participation. Furthermore, this work x-rays the role of education in empowering women in industry. It discusses the challenges and prospects of women in industry and proffers solutions for their empowerment.

It is a fact that, when women are empowered with education, their potentials are harnessed for sustainable economic growth which will not only benefit the nations at present but will also benefit the future generations. Thus, for Nigeria to excel and compete favorably with other nations in the field of industries, women must be given opportunity like their counterparts in other countries. Thus, there is need to strongly focus on the development of women by removing every obstacle that hinders women from making their impact. In fact, a study of the socio-economic characteristics, motivational factors and challenges, will help policy makers to properly target the problems faced by women in industry (Shukurana, 2018). This confirms the assertion of theWorld Bank in 2001, that investing in more women's business rather than men leads to greater development of a nation (World Bank Statistic 2001).

Therefore, importance of education as a fundamental tool for the empowerment of women can never be over emphasized because education serves as a catalyst for development and growth in every sector of the economy. When women are educated, they can compete favorably with their male counterparts and make positive impact in every sphere. Educated women not only improve the standard of living of their families but also help in the reduction and eradication 
of poverty. In fact, educated women are drivers of industrialization in many developed economies. However, there are many factors that downplay their effective participation in industry. Hence, this work aims at examining the legal framework that provides for the protection of women. Furthermore, this work analyses the factors that impede women from participating fully in industry and proffers recommendations. The work observes that, although legal measures have been put in place for full participation of women in industry at the international, regional and domestic levels, women have not made as much impact as their male counterparts.

Thus, the main objective of this study is to, x-ray the prospects and challenges of women in industry, examine the importance of education as a catalyst for development of a nation and proffer viable solutions.

\subsection{Meaning and Concept of Women in Industry:}

The word 'industry' has been defined as diligence in the performance of a task, a systematic labor for some useful purpose, especially a particular form or branch of productive labor; an aggregate of enterprises employing similar to produce items that have similar marketing characteristics. While the Chamber's Dictionary defines industrialisation as relating to or consisting in industry or an industrial worker and defines industrialization as character of industrialism devotion to labour. Industrialism means devotion to labour or industrial pursuits; that system or condition of society in which industrial labour is the chief and most characteristic feature.

While, Pareek defines the woman entrepreneur as a female who plays a captivating part by repeatedly interacting and keenly adjusting herself to financial, economic, and support spheres in the society. Globally, the impact of women entrepreneurs is gaining recognition intensely. Currently, women are underrepresented in industry; for instance, women represent $51 \%$ of the world population and drive $80 \%$ of household spending in United States, (Jemma, 2018). Worldwide, the number of female business owners continues to increase steadily and women in industry are making a positive impact on the global economy. For instance, women produce over 80 percent of the food for sub-Saharan Africa, 50-60 percent for Asia, 26 percent for the Caribbean, 34 percent for North Africa and the middle East, and more than 30 percent in Latin America (Shukurana and Adamu, 2018).

Thus, women entrepreneurs around the world are major contributors to the economy as they are making a difference in the socio-economic arena. They contribute numerous ideas and a great deal of energy and capital resources to their communities, and generate jobs as well as create additional work for suppliers and other spin-off businesses.

The role of women in industry is very germane because women are the key to economic growth and economic development. This decade has witnessed quite a number of women doing exploits in industry but many are still under represented. Thus, women should be given opportunity to showcase their talents and use their potentials to move the nation to another level. So, women in the small-scale businesses should be given opportunity to successfully exploit the world of industry. Women in industry are major contributors to economic growth because, without any doubt, they generate employment. The contribution of women is no longer debatable as numerous scholars attest that African women provide $60-80 \%$ of the food for family consumption and that the economic growth of some nations is attributable to female entrepreneurs (National Bureau of Statistics, 2008). 
This trend is even enhanced in the face of the global economic meltdown. The last official 2006 census, showed that Nigeria had a population estimate of 140, 431, 790 people. However, as at 2013, the population figure was estimated at 174 million. Statistics have shown that women constitute about $50 \%$ of the Nigerian population, and out of this, only about $35 \%$ of them are involved in any sort of entrepreneurial activity which can be under the form of micro, small, medium and large enterprises. Small scale enterprises and women empowerment are strong indications of the growth of a place (Population Reference Bureau, 2013).

\subsection{The Legal Framework:}

There are many legal measures towards mainstreaming women in industries and they include the following: Universal Declaration of Human Rights 1948, International Covenant of Economic, Social and Cultural Rights 1966, International Covenant on Civil and Political Rights 1966, Convention on the Nationality of Married Women 1957, Convention on the Elimination of All Forms of Discrimination against Women (CEDAW), Convention on Consent to Marriage, Minimum Age for Marriage and Registration of Marriages 1962, Convention on the Rights of the Child (CRC) 1989, and Worst Forms of Child Labour Convention 1999. However, for the purpose of this work, only a few were discussed.

\subsection{The International Framework:}

(1) The Universal Declaration of Human Rights:

This Charter extols its faith in the fundamental human rights, in the dignity and worth of the human person, and in the equal rights of men and women, and has determined to promote social progress and better standards of life in larger freedom. Thus, Article 2 provides that everyone is entitled to all the rights and freedoms set forth in this Declaration without distinctions of any kind such as race, colour, sex, language, religion, political or other opinion, national or social origin, property, birth or other status. While Article 23 provides that everyone has the right to work, to free choice of employment, to just and favourable conditions of work and to protection against unemployment. Also, everyone, without any discrimination, has the right to equal pay, for equal work and provides for just and favorable remuneration, ensuring for himself and his family an existence worthy of human dignity, and supplemented, if necessary, by other means of social protection. Furthermore, it provides that, everyone has the right to form and join trade unions for the protection of his or her interests.

On the other hand, Article 24 provides that everyone has the right to rest and leisure, including reasonable limitation of working hours and periodic holidays with pay. While Article 26 provides that everyone has the right to education and shall be free, at least, in the elementary and fundamental stages. It provides that elementary education shall be compulsory while technical and professional education shall be made generally available and higher education shall be equally accessible to all on the basis of merit. Importantly, education shall be directed to the full development of the human personality and to the strengthening of respect for human rights and fundamental freedoms. Parents have a prior right to choose the kind of education that shall be given to their children.

Furthermore, the International Covenant on Economic, Social and Cultural Rights, International Covenant on Civil and Political Rights and the Convention on the Rights of the Child are general instruments which recognize non-discrimination against women. As a member of the United Nations, Nigeria has signed and ratified these documents, specifically on protection of women. Such instruments include Declaration on the Elimination of 
Discrimination Against Women and the Convention on the Elimination of All Forms of Discrimination Against Women (CEDAW). Specifically, CEDAW notes that discrimination against women violates the principles of equality of rights and respect for human dignity, and respect to the participation of women, on equal terms with men, in the political social, economic, and cultural life of their countries. It notes that discrimination hampers the growth, and prosperity of society and the family and makes it more difficult for the full development of the potentialities of women in the service of their countries and of humanity. Concerned that with respect to poverty, health, education, training and opportunities for employment and other needs, women suffer more than their male counterparts. This instrument is convinced that the establishment of the new international economic order, based on equity and justice, will contribute significantly towards the promotion of equality between men and women. Thus, Article 2 reiterates that state parties should condemn discrimination against women in all its forms; agree to pursue, by all appropriate measures and without delay, a policy of eliminating discrimination against women and, to this end, undertake to embody the principle of equality of men and women in their national constitutions or other appropriate legislation, if not yet incorporated therein, and to ensure, through law and other appropriate means, the practical realization of this principle. Government, should adopt appropriate legislative and other measures, including sanctions where appropriate, prohibiting all discrimination against women. Also, government shall establish legal protection of the rights of women on an equal basis with men and to ensure through competent national tribunals and other public institutions the effective protection of women against any act of discrimination. The charter provides that State Parties should refrain from engaging in any discrimination against women and to ensure that public authorities and institutions shall act in conformity with this obligation. To take all appropriate measures to eliminate discrimination against women by any person, organization or enterprise. Further, to take all appropriate measures, including legislation, to modify or abolish existing laws, regulations, customs and practices which constitute discrimination against women. Furthermore, to repeal all national penal provisions which constitute discrimination against women.

The ratification of the Convention on the Elimination of Discrimination Against Women (CEDAW) and its optional protocols by Nigeria is a genuine commitment by the country that it will be bound by its provisions. It is a further re-assurance by Nigeria that all laws antithetical to women's development, which impede women's success, will be amended, repealed or abolished. However, up till now, CEDAW, has not been domesticated by Nigeria in line with the constitutional provision. The implication of non-domestication of CEDAW is that Nigeria's commitment remains mere aspirations.

\subsubsection{Regional Instruments:}

At the regional level, the African Charter on Human and Peoples Rights recognizes women's rights in some significant and peculiar ways. Nigeria signed the Charter on 3 August, 1982, ratified it on 22 June, 1983 and deposited it on 22 July, 1983. With this development, Nigeria is, ordinarily, bound by its provisions. Thus, non-compliance with or a breach of any of its provisions may be challenged in the Nigerian law courts. Precisely, it enforces the principle of equality and non-discrimination. Furthermore, it reiterates that every individual shall have the right to work under equitable and satisfactory conditions, and shall receive equal pay for equal work. It provides further that, the right to property shall be guaranteed to all (African Charter on Human and Peoples Right, 1982). 


\subsubsection{The 1999 Constitution (as amended):}

The Constitution of the Federal Republic of Nigeria made copious provisions for the protection of women in every sphere. However, the dichotomy visible in the Constitution is a challenge to the realization of those rights that ought to protect women. There are fundamental rights enshrined in Chapter IV, justiciable, and any person can seek redress under its umbrella once there is a breach or likelihood of such breach. Also, there are fundamental objectives contained in Chapter II, though not justiciable. Meaning that those rights cannot be redressed in court when there is a breach of such rights. Regrettably the right to education is enshrined in Chapter (II) that is not enforceable. However, with respect to this Chapter (II) which provides for economic objectives principles, the constitution provides that the state shall do the following:

(a) Harness the resources of the nation and promote national prosperity, an efficient, dynamic and self-reliant economy;

(b) Control the national economy in such a manner as to secure the maximum welfare, freedom and happiness of every citizen on the basis of social justice and equality of status and opportunity;

(c) Without prejudice to its right to operate or participate in areas of the economy, other than the major sectors of the economy, manage and operate the right of every citizen to engage in any economic activities outside the major sectors of the economy.

(d) The state shall direct its policy towards ensuring:

(a) The promotion of a planned and balanced economic development;

(b) That the material resources of the nation are harnessed and distributed as best as is possible to serve the common good.

(c) That the economic system is not operated in such a manner as to permit the concentration of wealth or the means of production and exchange in the hands of few individuals or of a group, and

(d) That suitable and adequate shelter, suitable and adequate food, reasonable national minimum living wage, old age care and pensions, and unemployment/sick benefits and welfare of the disabled are provided for all citizens. (Constitution of Federal Republic of Nigeria,1999).

The question that this elegant provision brings to fore, is whether the Government of Nigeria can achieve these lofty ideal provisions, without making (Chapter II) of the Constitution enforceable. The truth is that no one can enforce those rights in the Courts in Nigeria because they are not justiciable, particularly, with respect to education, even though the Constitution provides that, government shall strive to eradicate illiteracy and provide free, compulsory and universal primary education, free secondary education and free adult literacy programmes. Apart from non-justiciability of Chapter (II), which puts women in a precarious situation, to perfect the deal, section 6 (6) (c) of the constitution ousts the jurisdiction of the courts from entertaining any matter under the said Chapter II of the constitution. In fact, Section 6 (6) (c) provides as follows:

The judicial powers... 'shall not, except as otherwise provided by this constitution, extend to any issue or question as to whether any act or omission by any authority or person or as to whether 
any law or any judicial decision is in conformity with the fundamental objectives and directive principles of state policy set out in Chapter II of this constitution'.

The implication is that those rights contained therein are rendered unenforceable through the courts. This is in spite of the constant use of the word 'shall' in virtually all the sections of the chapter a word that, in normal judicial interpretative parlance, imports an obligation. While this is the case in most African countries, these economic, social and cultural rights have been entrenched as enforceable in the enterprising. Basic Law of the Federal Republic of Germany, for instance, and those of most Euro-American countries. Apart from that, another bottleneck to the enforceability of the relevant rights is the effect of section 12 (1) of the 1999 Constitution. It provides that "no treaty between the Federation of Nigeria and any other country shall have the force of law except to the extent to which any such treaty has been enacted into law by the National Assembly.

What this means is that the provisions of international law do not bind Nigeria and Nigerians, save and except if the law has been domesticated and incorporated into Nigerian corpus juris by an act of the National Assembly. It is immaterial that Nigeria is a signatory to such international treaties or conventions. This jurisprudence is, no doubt, contrary to the naturalization monistic policy that sees international law as binding on any country that is a party to it, especially, without reservation (pacta sunt servanda). This is in line with Article 27 of the Vienna Convention on the Law of Treaties, which cannot plead its domestic law to circumvent its international obligations. However, the domino effect of the Nigerian dualistic approach to international law is that the economic, social and cultural rights enshrined in them are neither justiciable nor enforceable. Fortunately, however, the African Charter on Human and Peoples Right (1981) has been domesticated as part of Nigerian municipal laws. Presently, it is incorporated as Chapter A9 of the Laws of the Federation of Nigeria, 2004. (Oraegbunam,2015)

\subsubsection{The Challenges of Women in Industry:}

The Factors that impede women from making giant strides in industry for the purpose of this study were grouped under legal and cultural factors.

(1) The Legal Factor

(i) Lack of implementation of our laws.

The major problem that hinders women from making a positive impact in the field of industry is the lack of implementation of laws. The laws are there because sufficient legal mechanisms have been put in place at the international, regional and domestic levels but many factors like non domestication of international laws that provide for protection of women are not implemented. For instance, there is the Convention on the Elimination of All Forms of Discrimination Against Women. But then, that non justiciability of Chapter (II) of the 1999 Constitution is a major drawback to the effective implementation of the provisions of the convention in Nigeria.

\section{(2) Traditional/Cultural Practices:}

Culture can be defined as the norms, practices and values of a particular society which have developed over a long period of time. It is also regarded as a set of distinctive spiritual, material, intellectual, and emotional features of society or a social group, and it encompasses, in addition to art and literature, lifestyle, ways of living together, value system, traditions and 
beliefs. Culture therefore includes beliefs and norms which regulate power relations and decision-making within the community at large and the family. It is based on these norms and beliefs that societies assign their expected characteristics to each sex. For example, in some African cultures, women are taught while men are encouraged to be strong, fearless and explorative (Avruch, 2004). Thus, by nature, men have already been prepared to explore according to their culture, unlike women who need to be pushed to be able to take decisions. Hence, women must be encouraged to shed all cultural practices that inhibit them from venturing into business, trade and industrialization in order to compete favorably with their male counterparts.

\section{(i) The Denial of Property Rights:}

Under the traditional cultural practices in Nigeria, women generally, have no property and inheritance rights except those conferred by will or statute. Over the decades, changes in the socio-political life of the global society have occasioned concerns and calls by jurists in all spheres for the modification of Nigerian customary practices, including those relating to inheritance, the one most antithetical to the promotion of equality between the male and female gender (Onuoha, 2013). These concerns found the most vocal and impactful expression, firstly, in the High Court and Court of Appeal decisions in Mojekwu v. Mojekwu, later affirmed by the Supreme Court under the title Mojekwu v. Iwuchukwu and secondly, by the earlier decision of the Supreme Court in Akinnubi v. Akinnubi. Apart from these and other similar decisions, thereafter, there have also been constitutional, statutory and treaty interventions aimed at promoting the succession rights of women.

Under most ancient African cultures that practice the primogeniture system of inheritance which follows the male lineage, only the eldest surviving son of a parent who died intestate inherits the entire estate of his deceased parent to the exclusion of his siblings irrespective of whether or not he is first in line among other children. In practice, however, the rule allows younger male siblings, in the family to enjoy the discretion of the eldest son in the distribution of the estate of the deceased, leaving out the female children and the widows. Where the eldest son predeceases the parents, the estate of the parents, upon their death intestate, devolves on either the eldest male child or the deceased's eldest son; or where there is none, on the next son in line after the deceased's eldest son, or his own eldest son in the event that he is no longer alive at the time. With respect to widows, customary laws of inheritance across the country (apart from Moslem Customary Law), confer no inheritance rights whatsoever on widows of deceased who die intestate. The widow of a deceased intestate property owner being a chattel and part of the husband's estate herself under customary laws could not inherit or administer the estate of her husband. This was reiterated in the case of Bikahu v. Akapo where the court while determining whether or not the widows of a Yoruba Chief who died intestate were entitled to be granted letters of administration over the estate of a deceased who died intestate, stated as follows: The only persons entitled to the grant of a letter of administration under Yoruba native law and custom... were the plaintiffs, four of the children of the deceased, but not the wives who are regarded as part of his estate. In Aleru v. Anibi, the court held that the widows were not suitable persons to be granted letters of administration. The court then appointed, suo motu, the Administrator-General to administer the estate at issue.

While acknowledging the existence of discriminatory customs relating to succession rights of widows among the Yoruba, the court stated, under Moslem law, the widow (s) portion of the estate of a deceased husband is one -eighth of the estate, shared equally amongst all the widows. Where there is Oshilaja v. Oshilaja that the customary law that a widow could not 
inherit her deceased husband's property had become so notorious that it had become judicially noticed. Earlier, the Federal Supreme Court had categorically affirmed this customary law's position in Suberu v. Sunmonu, where it held that, by Yoruba custom, a wife could not inherit her husband's property and that in the absence of any surviving child, the property of the deceased would be inherited by the members of his family. However, the case is not the same if it is the man that survived the woman.

This attitude leaves many women, especially widows, in a precarious situation and they keep on struggling without making a positive impact in the society. Thus, many do not have a solid financial base to start their business. Hence, only a few women thrive in business, trade or small-scale industry because they don't have access to landed property that they can use as collateral for loans. In fact, in cases where the widow is without any child, she inherits onequarter of the deceased husband's estate. This trend has crippled a lot of women from engaging in any trade or enterprises, and remain vulnerable without making impact. It is therefore suggested that every obstacle that hinders women from obtaining education should be jettisoned so that they can engage in gainful employment.

\section{(ii) Early Marriage and the Peference for Male Children:}

One of the things that impede the rights of women in Industry is son preference which is a gross discrimination against the female child. This negative attitude has hindered many female children from having education, thus making them vulnerable. It also limits them from making a positive impact in the society. Especially, where resources are limited, the female children are normally given out in marriage while the males are sent to school. This cultural practice has maimed many women by keeping them in perpetual poverty.

Apart from these major factors, the challenges of women in industry also include lack of access to credit facilities, poor information flow, weak linkages among different sectors, weak capabilities in terms of skills, lack of knowledge and lack of infrastructural facilities. Others include use of obsolete equipment and methods of production, inability to access new technology, poor accounting system, multiple taxation, unstable policies and low social status.

\subsection{Conclusion:}

The study observes that education is a veritable tool for industrialization which leads to national development and that educated women do better than their uneducated counterparts in industry. In fact, women involved in industry improve the level of comfort of their families, enjoy better healthcare and skill acquisition. Hence, encouraging women to acquire education will maximize their potentials and make them contribute meaningfully to the development of the nation. The work reveals that educated women in industry are more productive than their counterparts that are not educated. Hence, government should make policies to enhance female education and provide a conducive environment for productivity. The government should encourage the female child by giving them scholarships for quality education. Also, Government should introduce informal education like establishing more vocational training centres, to enable more women acquire skills that will make them relevant in industry. The government should also organize platforms to sensitize women on the need for continuous self-development and capacity building. 


\subsection{The Recommendations:}

Government should review our laws; in particular, chapter (ii) of the 1999 constitution (as amended) should be shifted to chapter (iv) and made justiciable so that women will enjoy their socio-economic rights, especially the right to education.

(1) Government should make policies that will encourage female education, especially beyond secondary school.

(2) Government should domesticate international legal instruments that provide for protection of women in every sphere.

(3) Government should take proactive measures to implement our laws.

(4) State Parties should give women managerial lessons accompanied with skill acquisition program for them to understand the rudiments of owning and sustaining a business.

(5) The courts should be very proactive in dealing with women, especially while dealing with inheritance matters.

(6) Government should provide basic infrastructures to improve women's access to industrialization, e.g. power, good roads, credit facilities.

(7) The legislators should take up their oversight functions in order to have effective implementation of the law.

(8) Women should be given continuous training in ICT, managerial studies and bookkeeping.

(9) There shall be review of all laws that discriminate against women.

(10) Young females should be motivated to channel their potentials into industries.

(11) There should be creation of awareness by the use of diverse means, example, sensitization of communities, working with the government at all levels, community leaders, traditional rulers, religious leaders and champions who can articulate issues effectively.

\section{Bibliography}

(1) Garner, B A, Black's Law Dictionary (9 ${ }^{\text {th }}$ edn U.S.A: Thomas West 2009).

(2) Kirk, E M Chambers $20^{\text {th }}$ Century Dictionary: (5 ${ }^{\text {th }}$ edn New Delhi India: Allied Publisher Private Limited 1983).

(3) Amigbogu, T U, Onwuteaka, CI, Edoko, T D, Okoli, M I, Roles of Small and Medium Scale Enterprises in Community Development: Evidence from Anambra South Senatorial Zone, Anambra State (2014) International Journal of Academic Research in Business and Social Science Vol. 4, No.8.

(4) Avruch, K "Culture as Context, Culture as Communication: Consideration" for Humanitarian Negotiators (2004) Harvard Negotiation Law Review. Vol 9 p. 393.

(5) Iyiola, O \& Azuli D, Women Entrepreneurs As Small Medium Enterprise, (SME) Operators and Their Roles in Socio-Economic Development in Ota, Nigeria (2014) International Journal of Economics Business and Finance Vol. 2 No1, Pp: 1-10, ISSN: 2327-8/88 (Online) Available online at http://ijebf.com/ accessed 5/6/2018.

(6) Oraegbuanam, I k E, Towards Enforcing of Rights to Adequate Health-Care in Nigeria Today, (2015) University of Jos Law Journal, vol.10, pp263-280. 
(7) Onuoha, V E, Ewere, A O, Succession Right Nigerian Women: A Mirror of the Pre \& Mojekwu Era (2013), N I A L S Journal of Law and Gender Maiden Edition P. 64-84.

(8) Shurkurana, M \& Jamilu A, Challenges and Prospects of Women Empowerment in Small Scale enterprises in Yobe State of Nigeria, Journal of Business and Economic Development Vol 2 No. 2, 2017, pp.87-93.

(9) Convention on the Elimination of All Forms of Discrimination Against Women G A Res. 34 /180, UN GA OR 34 Session Supplement No.46 UN Doc. A/34/46 1980. Reprinted in 19 ILM 331980 (it entered into force 3 September 1981).

(10) Covenant on the Rights of the Child G A Res. 25 (XLIV) UN G A or Res 2263 (XXII) (Nor. 7, 1967).

(11) Okeke .I, Women Empowerment As Catalyst for Economic Development http://www.sciencepublishinggroupcom/j/jbed > (accessed on 4/6/2018.

(12) Declaration on the Elimination of Discrimination Against Women, G A, Res, 2263 (XXII) (Nov 7, 1967).

(13) International Covenant on Economic Social and Cultural Rights (ICESCR) G A res. 2200A (XXI), 21 UNGAOR Supp (No.16) at 49. UN Doc. A/6316 (1966). 993 UNTS 3(entered into Force Jan 3 1970).

(14) Boosting Trade in Africa: Why Women Are the Key, http://www.worldbankorg/en/news/feature/2013/11/20/boosting accessed 6/6/2018.

(15) The African Charter on Human and People Rights OAU Doc. CAB/LEG/6713 Rev. 5 Reprinted in 21 ILM 581982 (it entered into force 21 October 1985)

(16) The International Covenant on Civil and Political Rights (ICCPR), CA res. 2200A)

(17) Mojekwu v Iwuchukwu (2004) II NWRL (Pt. 883)

(18) Mojekwu v Mojekwu (1997) 7 NWLR (Pt 512) 283.

(19) Oshilaja v Oshilaja (1974) 10 CCHCJ 54.

(20) Suberu v Sunmonu (1957) 2 FSC 33. 